\title{
ANÁLISIS
}

\section{Beyond Good Intentions. The Role of Self-Interest in Humanitarian Interventions. Looking back to the Australian Intervention in East Timor ${ }^{1}$}

DOI: $10.32870 /$ mycp.v4i10.476

Ruth Elizabeth Prado Pérez ${ }^{2}$

\begin{abstract}
Humanitarian intervention (HI) became a prominent feature of International Relations (IR) in the aftermath of the Cold War, and it set up the basis of what later developed as the Responsibility to Protect (R2P). From an International Relations perspective, the underlying debate developed around the question of was what provided the humanitarian character of an intervention. In that regard, little attention was paid to the role of self-interest in the decision-making processes leading to such interventions. This paper asks what are the crucial factors that explain when humanitarian emergencies actually lead to humanitarian interventions. It builds upon the frameworks developed
\end{abstract}

Artículo recibido el 8 de octubre de 2014 y dictaminado el 14 de noviembre de 2014 .

1. A preliminary version of this paper was presented at the International Studies Association Annual Conference 2010 at New Orleans.

2. Instituto Tecnológico y de Estudios Superiores de Occidente (ITESO), Departamento de Estudios Sociopolíticos y Jurídicos. Tlaquepaque, Jalisco, México. Correo electrónico: reprad@iteso.mx. Periférico Sur Manuel Gómez Morín 8585, Tlaquepaque, Jalisco, México. 
by Snyder, Bruck and Sapin (1962), and Rosenau (1966), which categorize five sources of influence in foreign policy decision making - external or global, societal, governmental, individual and role sources - to analyze an emblematic case of $\mathrm{HI}$ in the history of international relations, namely, the Australian-led intervention in East Timor. First, the paper looks at the theoretical explanations of HI. Secondly, the debate about the configuration of self-interest is reviewed. Next, the paper identifies the role that different sources played in the process that lead to HI. Finally, the decision making framework is applied to Australia's intervention in East Timor.

Keywords: humanitarian intervention, self-interest, decision-making, foreign policy, motives, sources of influence.

MÁs ALlÁ de LAS BUENAS INTENCIONES. EL PAPEL DEL INTERÉS NACIONAL EN LAS INTERVENCIONES HUMANITARIAS. UNA MIRADA A LA INTERVENCIÓN AUSTRALIANA EN TIMOR ORIENTAL

\section{Resumen}

La intervención humanitaria (IH) fue una de las figuras más recurrentes en las relaciones internacionales (RI) después de la Guerra Fría, y sentó las bases para lo que después se denominó la responsabilidad de proteger (R2P). Desde la perspectiva de las RI, el debate se centró en torno a la pregunta sobre ¿qué proveía el carácter humanitario de una intervención? Sin embargo, se prestó poca atención al papel del interés nacional en el proceso de toma de decisiones del cual emanaban dichas intervenciones. En este artículo se investiga qué factores son relevantes para explicar cuándo las emergencias humanitarias detonan intervenciones humanitarias. Se construye un análisis basado en el marco de toma de decisiones desarrollado por Snyder, Bruck y Sapin (1962), y Rosenau (1966), que propone cinco categorías que agrupan las fuentes de influencia que inciden en el proceso de toma de decisiones de la política exterior - externa o global, social, gubernamental, individual y el papel desempeñado por individuos- para analizar un caso de IH emblemático: la intervención liderada por Australia en Timor Oriental. Primero, en el artículo se examinan las aproximaciones teóricas que intentan explicar la IH. Segundo, se hace un recuento del debate en torno a la configuración del interés nacional. En el siguiente apartado se identifican cada una de las diferentes 
fuentes de influencia propuestas por el marco de Snyder et. al y Rosenau para comprender la toma de decisiones de política exterior. En el último apartado se analiza un caso de estudio: la intervención de Australia en Timor Oriental.

Palabras clave: intervención humanitaria, interés nacional, toma de decisiones, política exterior, fuentes de influencia.

\section{Humanitarian intervention in contemporary history}

The idea that a state could turn against its own people and, by action or omission, incur on massive human rights violations of its citizens, may sound senseless, since states are created precisely to protect them and provide for them. But in fact, the history of international relations offers numerous examples of situations where states commit serious human rights violations of their own citizens or failed to protect them from grave risks. Those situations usually produced what has been called extreme humanitarian crisis, that is, "a situation where there is a total or considerable breakdown of authority resulting from internal or external conflict which requires an international response that goes beyond the mandate or capacity of ant single agency and/ or ongoing UN country program" (IASC, 1994).

The way states and international organizations assess, deal and respond to humanitarian crisis go from total inaction to the use of armed force to stop the situation that is giving place to the emergency. Historically, the international responses have been shaped by several factors - economic, political, social, and geographical, believes and values, among others-. The influence of such factors in the process of deciding if, when and how to respond, has varied at different times and has been justified on different grounds by states and the international community. From all forms of response, the use of armed force to address a given humanitarian crisis, also known as humanitarian intervention, remains the most controversial due, among other things, to the selectivity that surrounds the decision-making process in each case.

In the aftermath of World War II, very much influenced by the horrors of the Holocaust, a body of human rights which forbid states to ill-treat individuals, including their own nationals, started developing at the recently created United Nations (UN). However, at the same time and in the UN, states were concerned with the devastating consequences of war and developed rules and principles guiding the right of states to use force, restricting it to cases of self-defense (Akehurst, 1984: 95). 
Thus, during the Cold War, there were some unfruitful attempts to legitimize the use of armed force for humanitarian purposes, but the lack of agreement over the rules that would regulate it, or more precisely, the risk of abuse to the sovereignty and non-intervention principles, persuaded states not to accept its practice. Hence, when the General Assembly was debating the definition of 'aggression' in 1954, with the Greek and Netherlands delegates arguing in favor of using force for in cases where there were ethnic ties between the intervening state and a racial minority suffering persecution in another state, the Israeli, Chinese and Panamanian delegates disagreed (Akehurst, 1984: 95) and, as a result, the use of armed force to save foreign nationals from the savagery of their own governments was ruled out (UN Charter Art. 2[4] and Art. 51).

Despite the discarding of humanitarian intervention as a way of addressing complex humanitarian emergencies in political turmoil, there are several Cold War examples of interventions by foreign countries in situations of widespread humanitarian suffering. The three most cited examples in the literature are the Indian intervention in Pakistan (1971), the Vietnamese intervention in Cambodia (1979) and Tanzania's intervention in Uganda (1979). These are cases where humanitarian interventions can arguably said to have been undertaken. But overall, it can be said that during that period the constraints imposed by the logic of the East-West confrontation resulted in humanitarian issues being relegated to a secondary place.

By early 1990s, however, with the Communist threat dissipated, optimism arose alongside the belief that a new humanitarianism was possible. The emergence of the humanitarian challenges posed by civil wars and internal conflicts that broke out at the time opened the possibility of efficiently addressing humanitarian emergencies. In this sense, a document produced by the General Secretary entitled "UN Peacekeeping in a New Era. A New Chance for Peace", optimistically described expanded peacekeeping with new and more ample responsibility in the area of human rights protection, such as the repatriation of refugees, assisting with reconstruction and providing aid for humanitarian delivery (Boutros Ghali, 1993: 67). Mayall (1996) calls this the New Interventionism era, a time when humanitarian intervention, as it was generally understood, was shaped by a reinvigorated idealism towards human rights protection abroad.

However, the period of optimism was brief and by 1994, the numerous conflicts and civil wars by far exceeded the UN's capacity and the world's will- 
ingness to address and get involved on humanitarian emergencies (Robert, 1993: 10). A more skeptical view of HI, seen with suspicion and distrust became the defining characteristic of the last decade of the twentieth century. But skepticism did not persuade states from getting involved and within that context, in 1999 the Australian-led intervention in East Timor took place. The Australian intervention could be considered emblematic for various reasons. First, it is one of the cases that that best fits into a traditional definition of $\mathrm{HI}$, not only because it was the response to a truly humanitarian emergency, but also because the intervention was specifically aimed at targeting the sources of the crisis. Secondly, because the intervention was very successful in achieving a positive humanitarian outcome. The success of this case in humanitarian terms, sealed with East Timor's independence, is precisely what distinguishes it from other cases during the post-Cold War era.

With the mixed results of HI towards the end of the Xx century, discussions about the use of humanitarianism as an excuse to intervene, the violation of the sovereignty when intervening and the lack of intervention in other cases, led former Secretary-General of the United Nations, Kofi Annan, to call for the international community to reach a consensus about what was to be understood by humanitarian intervention.

To this purpose, and at the initiative of the Canadian government, the International Commission on Intervention and State Sovereignty was established on 2000 (ICISS, 2001: 2). The Commission put forward the "Responsibility to Protect" (R2P) according to which, there is a responsibility to protect a human group in situations where their states are unable or unwilling to do so. The notion of R2P is ambitious since it implies three types of responsibility: to prevent, to react and to rebuild and establishes the four principles that should guide military intervention within the R2P - the just cause threshold, the precautionary principles and the right authority-. Despite the establishment of the R2P, in practice, military intervention for allegedly humanitarian purposes has largely remained a controversial feature of international politics.

\section{From Humanitarian Intervention to the Responsibility to Protect (R2P)}

Unlike other disciplines that have also studied Humanitarian Intervention — such as political science, international law, philosophy and even ethics-, 
IR theories appear to lack agreement about what defines the humanitarian character of this type of intervention, that is, what makes it different from any other intervention. This sort of skepticism of IR towards an intervention for humanitarian purposes is explained by the fact that $\mathrm{HI}$ challenges the basic principles and norms that have traditionally guided state's interaction. On the one hand is sovereignty, arguably one of the main pillars of the relations among states. Sovereignty es-

From an International

Relations perspective, intervention is at the core of the debate, since traditionally understood, the use of force has been reserved for cases of self-defense and therefore, defending someone else, in this case other state's nationals, from the savage of their own government, seems to break up the principles of non-interference in the internal affairs of other state and challenge that state sovereignty tablishes the non-interference of other states on internal matters, but does that include to ill-treat their citizens? On the other hand, is the use of force, which has traditionally been reserved for cases of self-defense?

There definitely has been a comprehensive debate on how to respond to massive human rights violations and how those situations may threat to peace and security and the focus has been on whether states should or should not intervene in those cases. The framework traditionally used in the study of humanitarian intervention derives from the international society approach, mainly related to Pluralism and Solidarism (Wheeler, 2000). This approach takes state boundaries to be the primary determinants of international politics, and consequently focuses on states, their borders and the norm of non-intervention.

Furthermore, from an International Relations perspective, intervention is at the core of the debate, since traditionally understood, the use of force has been reserved for cases of self-defense and therefore, defending someone else, in this case other state's nationals, from the savage of their own government, seems to break up the principles of non-interference in the internal affairs of other state and challenge that state sovereignty. 
IR practitioners, leaders, diplomats and government officials have focused the debate on when (or when not) to intervene. In this sense, Wheeler argues that intervention should be triggered by what he called a supreme humanitarian emergency since this concept "captures the exceptional nature of the cases under consideration" (2000: 34). However, there are no objective criteria for evaluating when a humanitarian emergency becomes supreme or when a supreme emergency becomes humanitarian. Therefore, the best way to define a supreme humanitarian emergency is, as Wheeler puts it, "when the only hope of saving lives depends on outsiders coming to rescue" (2000: 35).

Beyond how it is formally called, intervening abroad to save foreign nationals has given place to an extensive debate which has at its core the question of what determines the humanitarian character of this type of intervention. The two main positions in this debate are, on the one hand, that the purposes of the intervening state establish whether an intervention is humanitarian and, on the other, that it is the outcomes achieved by a given intervention what determine its humanitarian character.

Holzgrefe (2003), Murphy (1996), and Parekh (1997), who are purpose-oriented authors, have maintained that these interventions gain their legitimacy from their humanitarian aims, but they disagree on the extent to which the humanitarian motives ought to be the sole purpose, a primary motive or simply a component of the intervening state motivation (in Bellamy, 2004: 221). Teson (1997) and Wheeler (2000), who are outcome-oriented authors, argue that interventions in the context of complex humanitarian emergencies are legitimized by the positive humanitarian outcomes they produce. Wheeler (2000: 38-39) even suggests that the key caveat of this argument is that the means chosen by the intervener must not undermine a positive humanitarian outcome. The difficulty with this approach is that it is virtually impossible to fully know the outcomes of a given action beforehand.

Bellamy (2004: 224) argues that the main problem with both positions is that in the above debate, purposes and motives have often been used indistinctly. But "a state does not need to be motivated by humanitarian concerns to have a humanitarian purpose" (Bellamy, 2004: 225). For example, a state's motive for intervening may well be the promotion of liberal democracy, as a way of defending a given value and maintaining the balance of power. Arguably in this case the motive does not need to be humanitarian, but the actual purpose of stopping human rights abuses to advance a value may well be. In that sense, purposes could be the means by which motives are satisfied. 


\section{The Role of Self-Interest in Humanitarian Intervention}

A question that remains unanswered is what factors play a part in the decision-making process leading to humanitarian interventions. Arguably, a central but often maligned concept within that process is self-interest.

From a realist standpoint (Morgenthau, 1954; Kennan, 1954; Waltz, 1979), since most interventions are justified on moral grounds, the declared aims of an intervention invariably serve to mask the true intentions. ${ }^{3}$ Realists therefore tend to challenge any stated humanitarian aims of an intervention. Realists argue that non-humanitarian considerations are the underlying cause of humanitarian interventions. In fact, the non-humanitarian character of the motives behind the intervention determine its particular features, such as how the decision to intervene is made, when and how intervention is undertaken, and what the intervening state expects to get out of it. Consequently, interventions of this kind remain consistent with a broad definition of intervention as an act of interference in the domestic issues of another state. The only significant difference is that this type of intervention takes place in the context of a humanitarian emergency, sometimes even in the context of failed states, and its stated aim is to stop extreme human suffering.

The concept of self-interest is used both in political analysis and political action, referring to what is "best" for a state; it is therefore deeply rooted in the state's values. Morgenthau elucidates this by arguing that "the kind of interest determining political action in a particular period of history depends upon the political and cultural context within which foreign policy is formulated" (1954: 528), and that these contextual factors are defined in terms of power (1954: 8). It is worth drawing the line between self-interest and national interest, since both terms have been amply used in the Realist body of literature. Whilst self-interest presupposes a strategy to achieve what is best for the state, according to Huntington (1997), national interest derives from national identity, in other words, they are the interests provided by

3. When talking about morality we can distinguish between those Realists who emphasize a fixed human nature — such as Morgenthau and Niebuhr - also called biological Realists precisely due to the central role they place on human nature, and structural Realists like Waltz who believe that it is the anarchical structure of the international system that determines states behavior. Interestingly, despite the discrepancies, neither of these views is able to totally discharge morality from international relations. However, they are both skeptical about the intentions that states have for intervening in humanitarian catastrophes. 
the values and believes of a given country. Hence, "Efforts to define national interest presuppose agreement on the nature of the country whose interest are to be defined" (Huntington, 1997: 28). The national interest is the foundation for both the National Security Strategy and its supporting National Military Strategy (Roskin, 1994).

However, while analysts have found it difficult to use the concept of self-interest as a tool for rigorous research, actors have amply used the term as a way of thinking about their goals and mobilizing support for them. Not only do political actors tend to perceive their goals in terms of self-interest, but they also claim that their goals are about self-interest (Rosenau, 1980: 283). Decision makers define what is in the self-interest of a country and justify their actions in the pursuit of that self-interest. Its different uses reflect how problematic the concept of self-interest is. This poses the serious difficulty of distinguishing how self-interest, unlike other type of motives, determines what goals are pursued.

Applied to humanitarian intervention, self-interest can be understood as the strategic considerations that lead a state or states to believe that they are better served by getting involved in certain humanitarian crises abroad than by not doing so. Although this is a broad approach to self-interest in humanitarian intervention, it has several implications. First, it implies that the intervening state perceives intervention as serving its interest better than non-intervention would. Second, the intervening state decides how to intervene based on what is best for itself, not on the best way to deal with the humanitarian emergency. In other words, intervention is planned based on careful cost-benefit calculations for the intervening state. Third, the intervening state establishes the goals of the intervention based on what its own expected aims are, rather than on what would be required to solve the humanitarian emergency. This in turn suggests that the extent to which the intervention's outcome is positive in humanitarian terms is not necessarily a priority for the intervening state, unless it frames it as such.

The decision making framework developed by Snyder, Bruck and Sapin (1962) is based on the notion that political action is undertaken by concrete human beings and that in order to comprehend the dynamics of this action; it must be viewed from the perspective of these identifiable actors. To reconstruct the world of decision makers, Snyder outlined and categorized the main factors giving structure and content to their choices. The first category is the internal setting, which subsumes not only standard political phenomena 
such as public opinion, but also major common-value orientations, major characteristics of social organization, group structures and functions, major institutional patterns, and basic social processes. Secondly, the external setting comprises the actions and reactions of other states. Thirdly, there is the decision-making process, which Snyder et al (1962: 67) divides into three subcategories: spheres of competence, communication and information, and motivation. Taken together, these subcategories include the roles, norms, goals and functions within both the government and the particular unit making the decisions, and they are subjected to analysis (Rosenau, 1980: 301). It is this particular way of looking at self-interest that makes decision-making analysis a useful tool for examining the role of self-interest in humanitarian intervention because it encompasses the processes and sources of influence from which the intervention emerges.

In this sense, a systematic way of dealing with decision-making analysis is by using a model developed by Rosenau (1966) that categorizes the different sources of influence in the foreign policy decision-making process. The model posits five sources: external or global, which refer to the attributes of the international system and to the characteristics and behavior of the state and the nonstate actors comprising it; societal, which include those characteristics of the domestic social and political system that shape its orientation toward the world; governmental, which refer to those aspects of a government's structure that limit or enhance the foreign policy choices made by decision makers (Rosenau, 1980: 303); individual, which refer to the personal characteristics of decision makers, such as skills, personality, beliefs, and psychological predispositions, among others; and role sources, which refer to the structure of the government and the roles that people occupy within it. These sources help explain state behavior by examining the process in which self-interest is shaped.

\section{Decision Making in Humanitarian Intervention}

The obvious starting place for applying the above categories to the study of humanitarian intervention is the influence that the international system exerts on state behavior. The empirical evidence of the last fifty years clearly illustrates that the international system has been a key factor in influencing the practice of humanitarian intervention in two ways: by constraining it and by allowing it. 
Since the end of the Second World War, the international community has witnessed an unprecedented effort to create mechanisms for establishing universal human rights (1948), and to set minimum standards of internationally recognized human rights protection. However, far from determining state behavior, human rights values have been constrained by the international system itself. ${ }^{4}$ This explains why during the Cold War an intervention openly justified on humanitarian grounds would have been improbable.

A second factor in the decision-making process that determines the response to humanitarian emergencies is the type of government, which influences states' behavior. It has been suggested that, unlike other types of government, democratic regimes have to respond to their public, and therefore, they should not only ensure that their citizens enjoy human rights and civil liberties (Russett \& Oneal, 2001: 44), but also defend human rights values abroad. Other forms of government should not be disqualified de facto in the quest for human rights protection, and certainly not when it comes to humanitarian intervention. It is interesting to note that while some authoritarian countries may not hold good records on domestic human rights, they occasionally may get involve in interventions justified on moral grounds. Hence, one should carefully consider the type of government's influence on the decision to intervene with the particular circumstances of the case. ${ }^{5}$ However, it is not only the type but also the structure of the government which constrains or enhances the ability of state leaders to make decisions. The decision-making process in a democratic parliamentarian government may well differ from that of a presidential democratic system. Overall, however, the factors that would prompt a democracy to intervene are the same factors that may persuade leaders of other regime types to act. But other forms of government should not be disqualified automatically in the quest for human

4. For Solidarists, an international society is "a group of states which not merely form a system, in the sense that the behaviour of each is a necessary factor in the calculations of the others, as Realists would argue, but also have established by dialogue and consent certain common rules and institutions for the conduct of their relations, and recognize their common interest in maintaining these arrangements" (Bull and Watson, 1984: 1). In any case, either as a result of the lack of human rights values, norms and institutions which would have open the possibility for intervention, or as the consequence of the self-interested calculation within a bipolar world order where intervening for humanitarian reason would have been highly risky.

5. Andersson (2000) conducted a study to examine to what extent polity affect the incidence of UN-authorized operation and concluded that there is a positive association between the level of democracy and the propensity to participate in peacekeeping, including peace-support operation. 
rights protection, for example, Chad's participation in the intervention in the Central African Republic in 1997.

Related to the type of government is the social system of a state. The factors conforming the societal system of a state are those non-governmental aspects of a political system that influence its external behavior, such as value orientations, its degree of national unity, and the extent of its industrialization, among others (Rosenau, 1980). In general, the characteristics of a nation's society play a significant role in shaping its relations with other nations and its stance towards issues such as human rights. In contemporary cases of humanitarian intervention, societal factors have certainly been an important influence on decision makers, but whether or not their influence has actually determined intervention is difficult to know. Among these factors, the media, public opinion, NGOs and interest groups exert perhaps the greatest influence on humanitarian intervention. A well-known example of this is the role of the media in the Kurdish refugee crisis, which is said to have influenced the creation of the "safe havens" (Shaw, 2000: 35). Other societal factors are interest groups and NGOs. Interest groups are also capable of influencing policy choices, and in the case of humanitarian intervention, they may become important since they can mobilized support for the victims and favor a military intervention to face the situation. This may be the case when interest groups have specific links with the victims, when ethnic, racial or religious ties exist. ${ }^{6}$ NGOs for their part have considerably increased their presence in many countries. Domestic humanitarian NGOs are linked to or are branches of international NGOS and can pressure for the international

6. Example of this could be the case of the Pakistani government's brutal repression of the Bengali people in 1971, which mobilized the support of the Bengali people in India and led to the war between those two countries and the creation of Bangladesh after the Pakistani defeat. Explaining the reasons for the armed intervention, Indian Foreign Minister Sen argued: "we have... nothing but the purest of motives and the purest of intentions: to rescue the people of East Bengal from what they are suffering" (UN Doc. S/PV.1606 Dec. 4, 1971: 86).

The UN became involved in humanitarian activities in Sudan in 1989, when it launched a relief operation called Operation Lifeline Sudan, a consortium of UN agencies and three dozen nongovernmental organizations, to supply food and other humanitarian assistance to both government and rebel-controlled territories. However, both the Sudanese government and the rebels made it difficult for the UN and NGOs to work and in 2009, after the International Criminal Court indictment of President Omar El Bashir international and national humanitarian organizations and their personnel were expelled. The extensive humanitarian assistance provided by the NGOs to the affected people was important to on the one hand let the world know about the atrocities in Darfur and, on the other, to mobilize support for the Sudanese cause and the inclusion of the issue on the international agenda. 
community to intervene and can also take part in some operations. ${ }^{7}$ For example, NGOs played an important role in providing information about the situation in Sudan, which considerably influenced the inclusion of the topic on the international agenda.

Individual decision makers are relevant actors in policy making, and their ability to influence policy choices should be carefully considered. In general, approaches focusing on individual decision makers have looked at psychological and cognitive factors for explaining behavior. By analyzing specific aspects of individuals, these approaches have been able to bring clarity to decision-making analysis, particularly in situations of crisis. George (1960), for example, identifies an operational code for decision makers, a set of interconnected beliefs about political life which influence the actor's behavior.

Another advantage of using decision-making analysis is the possibility of evaluating the extent to which state leaders perceive - or misperceivesituations that may lead them to make a particular decision (Jervis, 1976). But of course, the capacity of individual decision makers is in turn determined by their position within the government and by the structure of the government itself.

For this reason, one would need to look at the particular role that the decision maker has within the government. Hence, role sources refer to the impact of the office on the behavior of its occupant. Because the positions that policymakers hold affect their behavior, policy outcomes can be influenced by the kinds of roles existing in the policymaking arena more than by the particular individuals who happen to be in authority at any given moment (Wittkopf et al., 2003: 23).

The sources examined above are able not only to influence the decision to intervene, but also to determine the intervention itself, how it is handled, by what means, and generally how the strategy for intervening is designed.

7. The UN became involved in humanitarian activities in Sudan in 1989, when it launched a relief operation called Operation Lifeline Sudan, a consortium of UN agencies and three dozen nongovernmental organizations, to supply food and other humanitarian assistance to both government and rebel-controlled territories. However, both the Sudanese government and the rebels made it difficult for the UN and NGOs to work and in 2009, after the International Criminal Court indictment of President Omar El Bashir international and national humanitarian organizations and their personnel were expelled. The extensive humanitarian assistance provided by the NGOs to the affected people was important to on the one hand let the world know about the atrocities in Darfur and, on the other, to mobilize support for the Sudanese cause and the inclusion of the issue on the international agenda. 
Australia's Self-Interest and the Fate of East Timor

The categories proposed by Snyder and Rosenau are valuable tools for explaining the Australian response to the humanitarian emergency that evolved in East Timor after 1974, when Indonesia illegally declared the annexation of the territory. This case offers the possibility of examining how the role played by self-interest influenced, to a great extent the international reaction to this case. The role played by Australia is particularly useful in explaining how considerations of self-interest not only took priority over the humanitarian concerns but also determined when and how the use of force to finally intervene was decided. In this section, the categories and subcategories proposed by Snyder and Rosenau are used to examine Australia's policy towards East Timor during and after the Cold War.

It is clear that under the principles that led to humanitarian interventions during the post-Cold War period, East Timor had long deserved to be considered a humanitarian emergency and consequently warranted intervention. However, the inaction that characterized the international response to the long history of human rights abuses in East Timor was largely framed by the external setting shaped by the Cold War. In 1974, when Portugal, the colonial power, abandoned the territory of East Timor with practically no thought about postcolonial arrangements, the West and Australia understood that, in the context of the Cold War, leaving East Timor on its own posed the danger of another Cuba that was simply not acceptable (Aubrey, 1998: 283). In contrast, at the time of the 1999 Australian intervention in East Timor, the external setting had considerably changed and the so-called humanitarian intervention became possible. In this context, Suharto's fall opened a window of opportunity for resolving the East Timor conflict.

The internal settings of Australian politics provide numerous elements for understanding Australia's response to the evolving humanitarian emergency in East Timor during and after the Cold War. For both periods of time, the configuration of Australia' self-interest offers a rather enlightening insight into the reasons that influenced Australia's position.

During the Cold War, Australia's self-interest was shaped by two main concerns: first, Australia's national security worries regarding Indonesia and second, Australia's interest in solving border disputes with East Timor.

With respect to the first point, from a strategic view, Indonesia is one of the most populous states in the world. Rather than engaging in a costly Cold 
War conflict with its neighbor, policymakers in Australia preferred to encourage good relationships with Suharto's regime (Leaver, 2001: 2-3), particularly after having dealt with Sukarno, the former Indonesian President, and his anti-Western policies. In this sense, the governmental sources provide several clues that suggest that Australian defense planning had long seen Indonesia as a potential threat and believed that military threats to Australia would come either from or through the Indonesian archipelago (Leaver, 2001: 12). It was therefore thought that Australia would be better served by promoting a stable pro-Western government in Jakarta and maintaining friendly relationships with it.

As pointed out previously, actors tend to perceive their goals in terms of self-interest and claim that their goals are about self-interest (Rosenau, 1966). In this regard, Australian governments, despite their party affiliation and political views on particular issues such as self-determination and human rights, made of Australia's good relations with Indonesia a self-interest priority even if that meant supporting the unlawful annexation of East Timor and disregarding the humanitarian crisis that unfolded afterwards. This may explain Australia' statements and actions to undermine the credibility of East Timor's struggle. Throughout the 1970s and 1980s, governments continually minimized the adverse publicity generated by the terrible accounts of abuse given by East Timorese refugees ${ }^{8}$. Australian support was crucial to the Indonesian military, both for the maintenance of this occupation and for its portrayal of East Timor in Indonesia (Taylor, 2003: 178).

Thus, in total contradiction to his progressive views on decolonization, Whitlam stated at a meeting with Suharto that Australian-Indonesian relations were the priority, and "an independent East Timor would be an unviable state and a potential threat to the area" (Hastings, Sydney Morning Herald, 16 September 1974). Along the same line, Prime Minister Whitlam's successor, the conservative Fraser, referred to the East Timorese as Communists, thereby de-legitimizing their struggle. Fraser and successive Australian governments were kept informed of developments in East Timor through annual reports

8. Example of this is Whitlam' statement when he said: "An independent Timor would be an unviable state and a political threat to the area."' (Stated by Prime Minister Gogh Whitlam to Indonesian President Suharto in September 1974 quoted by Ishizuka, K., 2004: 4). 
written by a former Australian consul to East Timor, James Dunn, ${ }^{9}$ who gave detailed descriptions of the human rights abuses (Aubrey, 2000: 149).

In 1978, following the de facto recognition of the Indonesian annexation of East Timor, Australia moved from a position of abstaining in the UN General Assembly resolutions which condemned the occupation of East Timor, to voting against them (Ball, 2001: 38). This policy was further extended when Australia became the only state to offer de jure recognition of Indonesia's annexation of East Timor. Canberra justified its diplomatic and legal endorsement of Indonesia's incorporation of East Timor by arguing that East Timor was an "unviable state" given the size and population of its territory, and in any event, it was "geographically natural" for East Timor to be integrated into the Indonesian archipelago (Dunn, 1995: 72). The Australian representative told the UN on 2 November 1979 that Australia "believed the question of the decolonisation of East Timor to have been resolved" (Maley, 2000: 65). This position is evidence of Australia's for Indonesia.

In 1983, when a Labour government came to power with Bob Hawke as prime minister, the new government suggested that those seeking to support East Timor would "do better to concentrate on helping the province through the provision of development aid and assistance" (Chinkin, 1995: 277). Australia's open support of Indonesia continued with the Labour government of Paul Keating. By September 1993, Keating went to Washington and urged President Clinton to withdraw human rights considerations from the drafting of economic and defense contracts (Aubrey, 2000: 144). This shows that Australian leaders and opinion-makers chose to prioritize the bilateral relationship with Indonesia as part of the country's self-interest.

Why did Australia decide to intervene to stop the continuation of humanitarian atrocities almost twenty-five years later? The lack of a consistent policy towards similar situations suggests that Australia's intervention in East Timor was not the result of a change in foreign policy, or at least not at its core, but rather grew out of a series of ad hoc decisions of a non-humanitarian character based on considerations of self-interest. Some scholars have documented that this kind of "dramatic reversal" in Australia's foreign policy is in fact not new (Clark, in Leaver, 2001: 9). Along these lines, Wheeler argues during Howard's government events outside the bilateral relationship transformed

9. From 1974 to 1985 , Dunn was Director of Foreign Affairs advisory body from the Foreign Affairs Group of the Legislative Research Centre. 
the East Timor question in the late 1990's (Wheeler \& Dunne, 2001: 811). However, this transformation by itself is not what explains Australian actions in East Timor; instead, we believe that the explanation lies in a redefinition of Australia's self-interest, very much influenced by the external setting, which remained a key factor in the international guiding of Australia.

During the 1990s, the situation in Indonesia had worsened. The country experienced very serious economic and financial crises that ultimately ended Suharto's regime (McCrum, The Observer, 24 May 1998: 28), perhaps affecting its strategic importance to the West. Moreover, the revolt against Jakarta in Aceh, ${ }^{10}$ West Papua, and, of course, East Timor during the final years of Suharto's regime and Kalimantan after Suharto's resignation, ${ }^{11}$ was evidence of the fragile situation and the difficulty in controlling over 13,000 islands and 300 ethnic groups. ${ }^{12}$ This situation explicitly concerned the Australian government and the country's national security. Whilst the partial fragmentation of Indonesia had the potential to defuse ethnic, regional and religious tensions that had been simmering throughout the archipelago for many years, it may also mean having to deal with the most ardent separatist groups located in East Timor, Aceh, and Irian Jaya until the process of complete independence was complete individually.

These changes in the external setting opened up the possibility for other sources of the foreign policy decision-making process to increase their influence on Australia's definition of its self-interest, which led it to review its position regarding East Timor. Furthermore, Australia's relationship with allies, particularly the United States (US), played also a significant role in Australia's rational for deciding to intervene in East Timor. The United States had the expectation that Australia would play a leading role in dealing with issues in maritime Southeast Asia and the Pacific islands (McDougall, 2002:

10. Tensions mounted in the province as a result of widespread support for the demand of a referendum on independence made by the Free Aceh Movement. By the end of March 1999, some 20,000 refugees were taking shelter in mosques and schools fearing reprisal by the security forces (Keesing Records of World Events, 1999, 42834). The government and representatives of the separatist Free Aceh Movement (GAM) on 9 December signed a peace agreement in Geneva, Switzerland, to end a rebellion in the north Sumatran province of Aceh that had begun in 1976 and cost some 12,000 lives.

11. A revolt in March forced the Indonesian government to dispatch 3,000 troops and paramilitary to the province (Keesing Records of World Events, 1999, 42496).

12. The artificial Indonesian nationalism, the absence of national values and anti-Javanese resentment in the outer provinces produced a post-colonial structure that was much more fragile than Australia was prepared to admit. 
591). The UN itself looks at Australia as a reliable contributor to peacekeeping operations which has reinforced a self-portrait image of "good member" in the international community.

Firstly, Australia's public opinion strongly supported an intervention in East Timor to stop the terrible history of human rights abuses by Indonesia. In Australia there had been long-term support for an independent East Timor among certain sectors. The Catholic Church, the ranks of returned soldiers who had memories of the Timorese support for Australian troops during the Pacific War, and even the left wing of the Labor Party were some of the supporters of the non-recognition of the Indonesian annexation of East Timor (Lever, 2001: 3-4). These sectors remained firm in their support for the island, and popular rejection of the occupation increased in 1991, when Indonesian troops opened fire on a memorial procession to a cemetery in Dili, killing 271 East Timorese. Images were broadcasted around the world, which mobilized international support for East Timor. Australia's public opinion openly rejected the Indonesian abuses.

Australian public support for East Timor continued during the following years. In the aftermath of the pro-independence result in the referendum of 1999, in Australia, there was a perception that the Indonesian military and pro-Indonesian militias were deliberately undermining the referendum result, either to punish the East Timorese for voting the way they did or else to create conditions such that Indonesia would have to remain (McDougall \& Kingsley, 2007: 22). Poll figures published in the Sydney Morning Herald on 14 September 1999 reveal the strength of Australian public opinion in response to this situation: 72 per cent of respondents supported the dispatch of peacekeeping troops to East Timor, with 34 per cent saying that Australia should intervene even without UN authorization (see McDougall, 2002: 191).

According to Lever, "the widening gap between the official and mass perceptions of Australia's relationship with Indonesia nonetheless had the effect of widely preparing the ground for an abrupt-face in Canberra's policy" (Lever, 2001: 4). Therefore, in 1999, when Howard decided to lead the international force for intervening in East Timor, his decision would prove to be immensely popular. But it would be oversimplified to argue that Australian policy was simply based on the government response to a strongly articulated public opinion.

Secondly, individual sources related to Howard's personal believes and perceptions about what he considered best for Australia played an impor- 
tant role in influencing his decisions. After Howard took office in 1996, he attempted to strategically reconsider some of Australia's "special" relationships, realizing that the relation with Indonesia needed to be devaluated for a number of reasons, including a need for other allies in the region before an eventual collapse of Suharto's regime in Indonesia. This is not to say that Howard wanted an abrupt change in Australia's position towards Indonesia. However, his personal views, combined with other sources of influence, helped to bring about the change in what he believed to be Australia's self interest. According to Howard, "[Australia] ha[d] a responsibility within its region to do things 'above and beyond', bringing into play its unique characteristics as a western country in Asia but with strong links to North America" (Brenchley, 1999: 22) and, therefore, Australia's intervention in East Timor showed her willingness to "help solve a difficult regional problem" (Brenchley, 1999: 22). To Howard, "East Timor peacekeeping shows Australia playing an 'influential, constructive and decisive role in the affairs of the region" (Brenchley, 1999: 22). But aware of the importance of Indonesia, Howard insisted that "unless the Indonesian authorities agree for the deployment of some peacekeeping force then it's just not legally possible forà" (Brenchley, 1999: 22). Howard's diplomacy and defense policy encountered during the East Timor crisis, became known as the 'Howard Doctrine' (Brenchley, 1999: 22; Lever, 2001: 1).

Thirdly, societal sources of influence had a significant impact on Australia's foreign policy. Australia, as a liberal democracy, promotes human rights values, and the long history of human rights abuses had been a topic of discussion among the general public, political parties, and other sectors of the population for some time. By 1999 it was clear that Australian society would support an intervention to stop the continuation of the human rights atrocities.

Together, all these factors helped to bring about what followed. In an unprecedented act, Australia's Prime Minister John Howard sent a letter to the new Indonesian President Habibie advocating enhanced autonomy (Aubrey, 2000: 144; Wheeler \& Dunne, 2001: 812). Howard's letter did not go further than what has already been established on the agreement of 5 of May 1999 between Indonesia and Portugal under the auspicious of the UN, but on his letter raised the benchmark of aspirations over East Timor claiming that the East Timorese were being denied the voice of Xanana Gusmao in a dialogue that would determine their future (Lever, 2001: 6). For a month, Habibie held a dead bat to Howard's suggestions and he was not alone. Clinton's Assistant Secretary for East Asian Affairs, Stanley Roth, criticized Howard's letter for 
crowding the field (Gray, 1999) and defended the already established UN agenda. But the effect of Howard's letter soon proved catalytic (Lever, 2001: 6). Howard was trying to encourage Habibie to consider a period of autonomy followed by an eventual act of self-determination, but Habibie went considerably further, promising a plebiscite, and that if the East Timorese voted for independence, it would be granted. Habibie would later declare that Howard's letter pushed him on the East Timor referendum ( $A B C$ News, 16 November 2008). Habibie had believed that he could rely on Australia's support to slow down pressures for political reforms, but with the letter he saw this expectation reduced (Thompson, 19 February 2007).

Did Howard mean to address the humanitarian issue by sending this letter? Most analysts agree that Howard never expected such a reply from Habibie and that the letter was more an attempt to reduce international criticism towards Indonesia than an expression of real humanitarian concern. In fact, Australian policymakers were aware of the importance of maintaining good relations with Indonesia, and therefore after the letter to Habibie, one of the priorities for Australia was the restoration of good faith with Indonesia by backing a strategic framework for the East Timor consultation process that was highly agreeable to Habibie. This may explain why, in the face of clear evidence in the summer of 1999 that greater security was needed to safeguard the voting process (The Guardian, 28 August 1999: 29), Australia waited and trusted the Indonesian forces to be in charge of security before and during the plebiscite.

\section{Conclusions}

IR scholars have been skeptical toward the idea that altruism and true human rights concerns explain outside intervention to save the nationals of foreign countries from acts or omissions of their own government which threaten their basic human rights. For that reason, it becomes relevant to examine why states intervene in some of these cases and not in others, and what determines the intervening state's response to a given humanitarian crisis.

This paper poses the question of what factors explain why humanitarian emergencies actually lead to humanitarian interventions, and seeks to answer that question by examining how states define their self-interest. The paper adopts a procedural notion of self-interest that maintains that foreign policy 
decision making is shaped by the interplay of sources and actors, from which the state's self-interest emerges.

Having examined the different factors that play a part in these processes, one can conclude that considerations of self-interest account for the different international responses to extreme humanitarian emergencies. Since humanitarian intervention is not usually ordered in response to a threat to the survival of the intervening state, it may well result from an indirect risk to national security, and/or represent a way of advancing the state's strategic interests. After all, humanitarian emergencies are more likely to take place in countries where vital interests are not at stake. This sort of intervention might offer a good reward in improving the intervening state's strategic position in the region/world or might be a response to domestic demands. Therefore, it is possible to talk about humanitarian interventions grounded in self-interest. This does not necessarily have to evoke a negative connotation. After all, if it is in a state's self-interest to stop the continuation of massive human rights abuses, that may well lead to a positive humanitarian outcome, which is the overall end of the so-called humanitarian intervention. In other words, whatever the motive is, if the purpose of a given intervention is humanitarian, it may well contribute to distinguish this type of intervention from other kinds.

The Australian intervention in East Timor is an emblematic case for illustrating the key role played by self-interest. Some scholars have highlighted the Australian decision to intervene in what seemed to be a risky military operation when self-interest was not vitally at stake. Certainly, the Australian government of Howard showed a greater degree of morality towards the humanitarian emergency in East Timor than prior Australian governments but these provide sufficiently solid evidence to ascribe to them Australia's decision to intervene.

The Australian involvement in East Timor was primarily the outcome of perceptions of national interest held by key decision makers (McDougall, 2002: 2) which, in turned, were influenced by different sources. Australia's refusal to send a force before the ballot — despite the intelligence documenting the pre-ballot violence and intimidation and the high probability of violence afterwards- are explained by its non-humanitarian motives. Australia's strategic self-interest was better served by doing something than by remaining a spectator. Australia could not afford inaction even if that implicitly meant accepting a foreign policy that could prove to be a failure. Moreover, the idea of Australia as a Western country in Asia with strong links to the U. S. 
had undermined its traditional position of support for Indonesia, making it impossible to continue dismissing the atrocities committed in a neighboring island so close to Australia. Having firmly opposed a pre-ballot peacekeeping force, Australia was forced by the circumstances to take the leading role in forming and commanding an international force to restore peace and security in East Timor.

A stronger argument pointing in this direction is that Australia's strategic self-interest was at stake with respect to the oil and gas resources that would have to be shared with an independent East Timor. Helping the East Timorese in the transition to independence would set a positive precedent in the relations between both countries. An analysis of the possible factors that account for Australia's intervention in East Timor makes it clear that self-interest played a significant role in determining the intervention, as well as when and how. However, it would be rather arbitrary to deny a certain degree of humanitarianism in Australia's involvement.

An examination of the decision-making process of Australia's policy towards East Timor shows how the different sources that shape foreign policy influence the standpoint of a state regarding humanitarian emergencies. As a result, when those sources change, as the external setting did during and after the Cold War, a change in foreign policy may ensue, resulting in dramatic changes in the state's response to humanitarian emergencies. Self-interest is what explains why similar humanitarian catastrophes receive different international responses.

\section{References}

Agreement between the Republic of Indonesia and the Portuguese Republic on the question of East Timor. (5 may, 1999). Accessed June 9 2010, available at http://www.un.int/portugal/acordos.htm

Akehurst, Michael (1984), 'Humanitarian Intervention', in Bull, Hedley (ed.), Intervention in World Politics, Oxford: Oxford University Press, pp. 95-118. Andersson, Andreas (2000), 'Democracies and UN Peacekeeping Operations, 1990-1996', International Peacekeeping, 7(2): 1-22.

Aubrey, Jim (1998), Free East Timor: Australia's culpability in East Timor Genocide, Sidney: Random House Australia. 
- (2000), 'Canberra: Jakarta's Trojan Horse in East Timor', in Hainsworth, Paul and McCloskey, Stephen (eds.), The East Timor Question: The struggle for independence from Indonesia. London: Ів Tauris Pub., 136.

Aus: Howard Interview Transcript. (6 September, 1999) Scoop Australia, Independent News, available at http://www.scoop.co.nz/stories/AU9909/ S00005.htm

Aus: Howard on East Timor. (29 September, 1999) Scoop Australia, Independent News, accessed 9 June 2010, available at http://www.scoop.co. nz/ stories/AU9909/S00063.htm

Australian Department of Foreign Affairs and Trade \#67 (2000), Australia and the Indonesian incorporation of Portuguese Timor: 1974-1976, Carlton: Melbourne University Press.

Ball, Desmond J. (2001), 'Silent Witness: Australian Intelligence and East Timor', Pacific Review, 114 (1): 35-62.

Bellamy, Alex J. (2004), 'Motives, outcomes, intent and the legitimacy of humanitarian intervention', Journal of Military Ethics, 3(3): 216-232.

Brenchley, Fred (1999), 'The Howard Defense Doctrine', The Bulletin, 28 September.

Bull, Hedley and Watson, Adam (1984), The expansion of international society, New York: Oxford University Press.

Chinkin, C. (1995), 'Australia and East Timor in international law', in CIIR and IPJET (ed.), International Law and the Question of East Timor, London: CIIR/IPJET.

Clarke, Gregory (1983), 'Vietnam, China and the foreign affairs debate in Australia: A personal account', in P. King (ed.), Australia's Vietnam, North Sydney: Allen \& Unwin.

Dunn, James (1995), 'The Timor Affair in International Perspective', in Cary, P. and Bentley, G. (eds.), East Timor at the Crossroads: The Forging of a Nation, London: Cassell.

East Timor bites the bullet (1999), The Guardian Weekly, September 28, available at http://www.guardian.co.uk/world/1999/aug/28/indo nesia. easttimor1

Garrett, Stephen (1999), Doing good and doing well: An examination of Humanitarian intervention, Westport, ст: Praeger.

George, Alexander (1960), 'The Operational Code: A Neglected Approach to the Study of Political Leaders and Decision-Making', International Studies Quarterly 13(2): 190-221. 
Ghali, Boutros Boutros (1993), 'Un Peace-Keeping in a New Era: A New Chance for Peace', World Today, 49(4): 66-69, Royal Institute of International Affairs.

Gray, Joanna (1999), 'Washington supports UN negotiations”, Australian Financial Review, 14 January.

Gunn, Geoffrey C. (1997), East Timor and the United Nations. The case for intervention, The Red Sea Press.

Hastings, P. (1974), 'Timor', Sydney Morning Herald, 16 September, pp. 126127.

Head, M. (2000), 'East Timor and Australia's oily politics', World Socialist Web Site, available at http://www.wsws.org/ articles/2000/mar2000/ timo-m08.shtml

Hoffman, Stanley (1995), 'The crisis of Liberal Internationalism', Foreign Policy, No. 98: 159-177.

- - (1996), The Ethics and Politics of Humanitarian Intervention, Notre Dame, IN: University of Notre Dame Press.

Holzgrefe, J. L. (2003), 'The Humanitarian Intervention Debate', in Holzgrefe, J. L. and Keohane, Robert O. (eds.), Humanitarian Intervention: Ethical, Legal and Political Dilemmas, Cambridge: Cambridge University Press.

Howard pushed me on E Timor referendum: Habibie (2008), ABC News, available at http://www.abc.net.au/news/ stories/2008/11/16/2420843.htm Hungtinton, Sammuel (1997). 'The Erosion of American National Interests', Foreign Affairs, 76(5): 28-49.

IASC, Inter-Agency Standing Committee, 10 ${ }^{\text {th }}$ meeting, December 1994.

International Commission on Intervention and State Sovereignty (ICISS) (2001), The Responsibility to Protect. Report of the International Commission on Intervention and State Sovereignty, Ottawa, Canada: International Development Research Centre.

Ishizuka, K. (2004), 'Australia's Policy Towards East Timor: Australia as Regional Hegemon?', UNU-CRIS Occasional Papers, available from: United Nations University, Department of International Business Management, University of Kyoei, available at: http://www.cris.unu.edu/fileadmin/ workingpapers/katsumi\%20ishizuka\%20occ\%20paper.pdf

Jervis, Robert (1976), Perception and Misperception in International Politics, Princeton: Princeton University Press.

Keesing's Records of World Events (1999a), 45(3): 42496, available http:// www.keesings.com 
—— (1999b), 45(3): 42834, available at http://www.keesings.com

Kennan, George (1954), Realities of American Foreign Policy, Princeton: Princeton University Press.

Leaver, Richard (2001), 'Introduction: Australia, East Timor and Indonesia', The Pacific Review, 14(12): 1-14.

Maley, William (2000), 'The UN and East Timor', Pacific Review 12(1): 63-76. Mayall, James (1996), The new interventionism 1991-1994, Cambridge: Cambridge University Press.

McCrum, R. (1998), 'Extra extra: Suharto should rot in hell tormented by the souls of East Timor', The Observer News, 24 May, p. 28.

McDougall, Derek (2002), 'Australian Peacekeeping role in the Post-Cold War Era', Contemporary Southeast Asia, 24(3): 590-608.

McDougall, Derek and Kingsley, Edney (2007), 'Howard's way? Public opinion as an influence on Australia's engagement with Asia', Paper presented at the annual conference of the Australasian Political Studies Association, Monash University, Melbourne.

Morgenthau, Hans (1954), Politics Among Nations: The Struggle for Power and Peace, New York: Alfred A. Knopf.

Murphy, Sean D. (1996), Humanitarian Intervention: The United Nations in an Evolving World Order, Philadelphia, PA: University of Pennsylvania Press. Parekh, Bhiku (1997), 'Rethinking Humanitarian Intervention', International Political Science Review 18(1): 55-74.

Pilger, John (1994), Distant Voices, New York: Arla Press.

Roberts, Adams (1993), 'The UN and International Security', Survival, 35(2), summer.

Rosenau, James (1966), Domestic Sources of Foreign Policy, New York, NY: The Free Press.

- - (1980), The Scientific Study of Foreign Policy, London: F. Pinter.

Roskin, Michael G. (1994), National interest: From abstraction to strategy, Carlisle: Strategic Studies Institute.

Russett, Bruce and Oneal, John R. (2001), Triangulating Peace: Democracy, Interdependence, and International Organizations, New York and London: W. W Norton and Company.

Shaw, Martin (2000), 'Media and Public Sphere without Borders? News coverage and Power from Kurdistan to Kosovo?', in Nacos, B. and Shaphiro, R. (ed.), Decision-making in a Glass House, Rowman and Littlefield Pub. 
Snyder, Richard C., Bruck, H. W., \& Sapin, B. (1962), Foreign Policy Decision Making. An Approach to the study of International Politics, Glencoe, IL: The Free Press of Glencoe.

Taylor, J. G. (2003), 'Encirclement and Annihilation. The Indonesian Occupation of East Timor', The Spectre of Genocide. Mass Murder in Historical perspective, Cambridge: Cambridge University Press.

Teson, Fernando R. (1997), Humanitarian Intervention: An Inquiry into Law and Morality, Irvington, NY: Transnational Publishers.

Thompson, G. (2007), 'Howard letter helped bring about E Timor independence poll', $A B C$ News, available at http://www.abc.net.au/news/ stories/2007/02/19/1851623.htm

United Nations (1971), 's/pV.1606', United Nations Document, p. 86.

Waltz, Kenneth (1979), Man, the State and War: A Theoretical Analysis, New York: Columbia University Press.

Wheeler, Nicholas (2000), Saving Strangers: Humanitarian Intervention in International Society, Oxford: Oxford University Press.

Wheeler, Nicholas and Dunne, Tim (2001), 'East Timor and the New Humanitarian Intervention', International Affairs, 77(4): 805-827.

Wittkopf, Eugene R., Kegley, Charles W. Jr., and James, M. S. (2003), American Foreign Policy: Pattern and Process, Belmont, CA: Thomson/Wadsworth. 